\title{
HUBUNGAN KESEJAHTERAAN PSIKOLOGIS DENGAN ASPIRASI KARIR SISWA SMA DI BANDAR LAMPUNG
}

\author{
Citra Abriani Maharani' ${ }^{1}$, Yohana Oktariana ${ }^{2}$
}

1,2Program Studi Bimbingan dan Konseling, Fakultas Keguruan dan IImu Pendidikan, Universitas Lampung, e-mail: citra.abriani@fkip.unila.com

\section{ABSTRACT : RELATIONSHIP OF PSYCHOLOGICAL WELL-BEING AND CAREER ASPIRATION AMONG HIGH SCHOOL STUDENTS IN BANDAR LAMPUNG}

Psychological well-being is the full achievement of a person's psychological potential which makes an individual able to function properly in carrying out all duties and responsibilities as an individual. This study aims to determine the relationship between the level of psychological well-being and career aspirations of high school students in Bandar Lampung. The sample in this study involved 88 high school students in Bandarlampung who were selected using cluster sampling. This research method is quantitative with a correlational research design. Measurement tools used in this study are a scale of psychological wellbeing and career aspirations. The analysis technique used in this research is the product moment correlation. The results showed that there is a strong relationship between psychological well-being and career aspirations of high school students in Bandarlampung.

\section{Keywords: Psychological Well-being, Career Aspirations, High School Student}

Kesejahteraan Psikologis merupakan pencapaian penuh dari potensi psikologis seseorang yang membuat individu mampu berfungsi dengan baik dalam mengerjakan segala tugas dan tanggung jawab sebagai individu. Penelitian ini bertujuan untuk mengetahui secara mendalam hubungan antara tingkat kesejahteraan psikologis terhadap aspirasi karir pada siswa SMA di Bandar Lampung. Sampel dalam penelitian ini melibatkan siswa SMA di Bandarlampung sebanyak 88 orang yang dipilih dengan menggunakan cluster sampling. Metode penelitian ini adalah kuantitatif dengan desain penelitian korelasional.. Alat pengukuran yang digunakan dalam penelitian ini berupa angket skala kesejahteraan psikologis dan skala aspirasi karir. Teknik analisis yang digunakan dalam penelitian ini adalah crelasion product moment. Hasil penelitian menunjukkan bahwa terdapat hubungan yang kuat antara kesejahteraan psikologis terhadap aspirasi karir siswa SMA di Bandarlampung.

\section{Kata kunci: Kesejahteraan Psikologis, Aspirasi Karir, Siswa SMA}

PENDAHULUAN

Setiap orang mendambakan kebahagiaan dalam hidupnya. Dalam meraih kebahagiaan tersebut ada sebagian orang yang terus berusaha semaksimal mungkin mencapai sukses, baik dalam belajar, bekerja, bekeluarga, maupun bermasyarakat. Mereka yang sukses biasanya menyenangi bidang pekerjaan yang digelutinya. Kesuksesan mereka itu diakui oleh teman-temannya dan masyarakat di sekitarnya. Berbagai upaya ditempuh mengingat hal tersebut menjadi tujuan hidup seseorang. Tingkat kebahagiaan individu dalam kehidupannya disebutkan sebagai derajat kesejahteraan psikologis. Menurut Akhtar (2009) menyatakan bahwa seseorang akan memiliki tingkat kesejahteraan psikologis yang lebih tinggi bila ia merasakan lebih banyak efek positif dibandingkan efek negative, begitupun sebaliknya. Kesejahteraan psikologis merupakan konsep yang terdapat di dalam Positive Psychology dan terbukti di dalam dua 


\section{HUBUNGAN KESEJAHTERAAN PSIKOLOGIS DENGAN ASPIRASI KARIR SISWA SMA DI BANDAR LAMPUNG}

dekade belakangan ini bahwa keadaan psikologis seseorang yang positif bukan hanya penting bagi kesehatan seseorang, melainkan juga dapat mempengaruhi proses penyembuhan maupun onset dari suatu penyakit atau permasalahan fisik (Vazquez, Hervas, Rahona, \& Gomez, 2009).

Siswa yang dapat secara bebas mengaktualisasikan dirinya, mampu untuk mengembangkan potensi secara berkelanjutan, dan memiliki motivasi untuk mencapai tujuan hidupnya, maka siswa tersebut akan mendapatkan kesejahteraan psikologis yang memadai. DC: Bureau of Justice Statistics; Guerino, Harrison, dan Sabol (2011) menjelaskan konsep kesejahteraan psikologis sebagai suatu kondisi dimana individu dapat menerima segala kelebihan dan kekurangannya, menggembangkan potensi diri secara berkelanjutan, memiliki tujuan hidup dan menemukan kebermaknaan hidup, membangun hubungan positif dengan orang lain mampu mengatur lingkungan secara efektif sesuai dengan kebutuhannya, serta memiliki kemampuan dalam menentukan tindakan sendiri.

Bagi siswa SMA, kesejahteraan psikologis juga diperlukan. Hal ini akan menunjang kondisi mereka dalam mengikuti kegiatan pembelajaran sehari-hari di sekolah. Namun, kenyataan dewasa ini, banyak siswa yang tidak menunjukkan kesejahteran pada psikologis mereka. Banyak sekali dari mereka yang tidak menunjukkan ciri-ciri sejahtera pada aspek psikologisnya. Hal ini tentu akan menghambat remaja dalam mengembangkan potensinya, salah satunya dengan tidak memahami karir yang akan mereka tentukan sebagai jalan untuk mencapai kesuksesan di masa

Tema sentral kehidupan anak yang berada pada masa remaja, dan perlu mendapat perhatian keluarga adalah pencarian identitas atau jati diri, baik yang berkaitan dengan aspek intelektual, sosial-emosional, vokasional maupun spiritual. Remaja harus mampu menjawab "Siapa Saya ", Mau kemana saya? dan lain sebagainya. Hal tersebut sejalan dengan yang diungkapkan oleh Santrock (dalam Nasrudin, 2017) masa remaja adalah periode perkembangan transisi dari masa kanak-kanak hingga masa dewasa yang mencakup perubahan-perubahan biologis, kognitif, dan sosial emosional.

Salah satu tugas perkembangan remaja yang harus dicapai adalah memilih dan mempersiapkan diri untuk menjalankan suatu pekerjaan. Menurut Hurlock (1980) pemilihan dan persiapan diri untuk menjalankan suatu pekerjaan atau karir merupakan tugas perkembangan yang penting di masa remaja.

Memiliki aspirasi karir adalah penting bagi siswa, karena dengan memiliki aspirasi karir yang jelas siswa dapat memiliih dan merencanakan karir sesuai dengan minat, harapan, cita-cita dan kemampuannya. Annete

Citra Abriani Maharani, Program Studi Bimbingan Konseling Fakultas Keguruan dan Ilmu Pendidikan Universitas Lampung. Email: citra.abriani@fkip.unila.ac.id

Yohana Oktariana, Program Studi Bimbingan Konseling Fakultas Keguruan dan Ilmu Pendidikan Universitas Lampung. 


\section{HUBUNGAN KESEJAHTERAAN PSIKOLOGIS DENGAN ASPIRASI KARIR SISWA SMA DI BANDAR LAMPUNG}

(2009) menyatakan bahwa aspirasi karir dianggap sebagai indikator penting dari sebuah karir di masa depan, mengingat kurangnya motivasi dan ambisi tidak akan mengarah pada posisi teratas, karena dengan memiliki tingkat aspirasi karir tinggi tidak hanya semata-mata memprediksi keberhasilan karir dalam organisasi besar saja, namun juga bisa menunjukkan sebuah cita-cita untuk menjadi sukses secara mandiri.

Adanya keinginan yang kuat dan telah melibatkan perencanaan atas usaha mewujudkan keinginan, harapan, dan cita-cita inilah yang menggambarkan aspirasi karir siswa, sedangkan aspirasi karir siswa itu sendiri dapat didefinisikan sebagai membangun mewujudkan identitas kerja individu dan tujuan karir yang diinginkan di masa depan (Danziger \& Eden, 2006).

Berdasarkan uraian tersebut, diperlukan kajian penelitian untuk membuktikan adanya hubungan antara tingkat kesejahteraan psikologis terhadap tingkat aspirasi karir siswa SMA di Bandarlampung. Hasil kajian ini akan menjadi landasan empiris untuk mengembangkan berbagai usaha yang mampu mendukung terwujudnya tujuan pembelajaran siswa secara lebih efektif di sekolah.

\section{METODE}

Teknik pengambilan sample dalam penelitian ini dilakukan dengan menggunakan teknik Cluster Sampling (Area Sampling) dan diperoleh 88 orang siswa SMA di Bandarlampung. Penelitian ini menggunakan dua alat pengumpulan data, yaitu skala kesejahteraan psikologis yang bertujuan untuk mengukur tingkat kesejahteraan psikologis siswa, dan skala aspirasi karir yang bertujuan untuk mengukur tingkat aspirasi karir siswa.

Skala kesejahteraan psikologis terdiri dari 42 item pertanyaan, 1 item tidak valid, sehingga total item adalah 41 item pertanyaan, dan terbukti reliabel $(\alpha=.954)$. Lebih lanjut, skala aspirasi karir terdiri dari 39 item pertanyaan dan juga terbukti reliabel $(\alpha=.868)$.

Teknik analisis data yang digunakan dalam penelitian ini adalah correlation product moment, untuk melihat hubungan kesejahteraan psikologis terhadap aspirasi karir siswa SMA di Bandarlampung.

Citra Abriani Maharani, Program Studi Bimbingan Konseling Fakultas Keguruan dan Ilmu Pendidikan Universitas Lampung. Email: citra.abriani@fkip.unila.ac.id

Yohana Oktariana, Program Studi Bimbingan Konseling Fakultas Keguruan dan Ilmu Pendidikan Universitas Lampung. 


\section{HUBUNGAN KESEJAHTERAAN PSIKOLOGIS DENGAN ASPIRASI KARIR SISWA SMA DI BANDAR LAMPUNG}

\section{HASIL}

Tabel 1

Kategorisasi Kesejahteraan Psikologis

\begin{tabular}{|c|c|c|c|}
\hline Kategori & Interval & $n$ & $\%$ \\
\hline Sangat tinggi & $108<X$ & 20 & 22.72 \\
\hline Tinggi & $60<x \leq 72$ & 52 & 58 \\
\hline Sedang & $48<X \leq 60$ & 1 & 1.12 \\
\hline Rendah & $36<x \leq 48$ & 14 & 15.9 \\
\hline Sangat rendah & $x \leq 36$ & 2 & 2.27 \\
\hline \multicolumn{2}{|c|}{ Jumlah } & 88 & 100 \\
\hline
\end{tabular}

Berdasarkan pada tabel 1 di atas, dapat diketahui bahwa sebagian besar siswa memiliki tingkat kesejahteraan psikologis yang tinggi yaitu sebesar $58 \%$, yang ditandai dengan memiliki kemampuan untuk berperilaku dan berpikir tanpa terpengaruh oleh tekanan sosial, memanfaatkan kesempatan yang ada disekitar dengan efektif, memiliki perasaan untuk selalu mengembangkan diri, peduli terhadap kesejahteraan orang lain, memiliki tujuan hidup dan perasaan yang terarah, dan memiliki sikap positif terhadap diri

\section{Tabel 2}

Kategorisasi Aspirasi Karir

\begin{tabular}{llll}
\hline \multicolumn{1}{c}{ Kategori } & \multicolumn{1}{c}{ Interval } & \multicolumn{2}{c}{$\%$} \\
\hline Sangat tinggi & $107,25<X$ & 26 & 29.55 \\
Tinggi & $90,75<X \leq 107,25$ & 42 & 47.72 \\
Sedang & $74,25<X \leq 90,75$ & 13 & 14.77 \\
Rendah & $57,75<X \leq 74,25$ & 7 & 7.95 \\
Sangat rendah & $X \leq 57,75$ & 0 & 0 \\
\hline \multicolumn{2}{c}{ Jumlah } & 88 & 100 \\
\hline
\end{tabular}

Berdasarkan pada tabel 2 di atas, dapat diketahui bahwa sebagian besar siswa memiliki tingkat aspirasi karir yang tinggi yaitu sebesar $47.72 \%$, yang ditandai dengan siswa sudah memiliki keinginan atau harapan atau cita-cita, ambisi, mimpi realistis dan sudah ada upaya untuk mencapainya apa yang dicita-citakan dan diimpikan tersebut. Lebih lanjut uji hipotesis menggunakan korelasi product moment Pearson. Berikut penjabarannya dapat dilihat pada tabel 3

Citra Abriani Maharani, Program Studi Bimbingan Konseling Fakultas Keguruan dan Ilmu Pendidikan Universitas Lampung. Email: citra.abriani@fkip.unila.ac.id

Yohana Oktariana, Program Studi Bimbingan Konseling Fakultas Keguruan dan Ilmu Pendidikan Universitas Lampung. 


\section{HUBUNGAN KESEJAHTERAAN PSIKOLOGIS DENGAN ASPIRASI KARIR SISWA SMA DI BANDAR LAMPUNG}

\section{Tabel 3}

Hasil Uji Hipotesis

\begin{tabular}{lll}
\hline & \multicolumn{1}{c}{ Aspirasi karir } \\
\hline Kesejahteraan psikologis & $.932^{* *}$ & \\
\hline${ }^{* *} p<.01$ &
\end{tabular}

Tabel di atas menunjukkan bahwa ada hubungan yang kuat dan signifikan antara kesejahteraan psikologis dengan aspirasi karir siswa $(r(88)=.932, p<.01)$. Hasil perhitungan tersebut juga menunjukkan bahwa kesejahteraan psikologis berkontribusi sebesar $86,9 \%$ dalam meningkatkan aspirasi karir siswa.

\section{DISKUSI}

Tujuan penelitian ini adalah untuk melihat adanya hubungan positif antara tingkat kesejahteraan psikologis dengan aspirasi karir siswa SMA di Bandar Lampung. Hasil penelitian menunjukkan bahwa hipotesis diterima yaitu terdapat hubungan yang signifikan antara tingkat kesejahteraan psikologis dengan asprasi karir siswa. Artinya disini, semakin baik tingkat kesejahteraan psikologis, maka akan semakin baik aspirasi karir siswa.

Menurut Dorji (2008) masa remaja adalah masa yang penting untuk memiliki aspirasi, karena dengan memiliki aspirasi siswa menjadi lebih percaya diri dan bangga akan dirinya, dan tentu saja ia akan merencanakan masa depan dan memiliki ambisi atau harapan untuk meraih cita-cita. Gottfredson (1981) juga mengungkapkan bahwa dalam tahapan perkembangan aspirasi karir, masa remaja memasuki tahap keempat atau tahap akhir yang dimulai pada usia 14 tahun dan seterusnya, dimana perkembangan berorientasi pada internal diri, dan juga keunikan diri sendiri.

Pendapat tersebut sejalan dengan aspek-aspek yang ada dalam kesejahteraan psikologis yang dikemukakan oleh Ryff (1989). la menjabarkan bahwa psychological well-being adalah suatu kondisi seseorang yang bukan hanya bebas dari tekanan atau masalahmasalah mental saja. Tetapi lebih dari itu yaitu kondisi seseorang yang mempunyai kemampuan menerima diri sendiri maupun kehidupannya di masa lalu (self-acceptance), pengembangan atau pertumbuhan diri (personal growth), keyakinan bahwa hidupnya bermakna dan memiliki tujuan (purpose in life), memiliki kualitas hubungan positif dengan orang lain (positive relationship with others), kapasitas untuk mengatur kehidupannya dan lingkungannya secara efektif (environmental mastery), dan kemampuan untuk menentukan tindakan sendiri (autonomy).

Citra Abriani Maharani, Program Studi Bimbingan Konseling Fakultas Keguruan dan Ilmu Pendidikan Universitas Lampung. Email: citra.abriani@fkip.unila.ac.id

Yohana Oktariana, Program Studi Bimbingan Konseling Fakultas Keguruan dan Ilmu Pendidikan Universitas Lampung. 


\section{HUBUNGAN KESEJAHTERAAN PSIKOLOGIS DENGAN ASPIRASI KARIR SISWA SMA DI BANDAR LAMPUNG}

Artinya adalah ketika siswa memiliki tingkat kesejahteraan psikologis yang baik, siswa akan mampu untuk meyakinkan dirinya bahwa hidupnya memiliki tujuan hidup yang bermakna, siswa juga akan lebih mampu untuk mengatur kehidupannya secara mandiri, mengambil keputusan sendiri, dan selalu berupaya untuk mengembangkan diri secara optimal.

Ryff (2014) juga menjelaskan bahwa individu yang memiliki otonomi yang positif akan memiliki determinasi diri \& kebebasan; mampu berperilaku dan berpikir tanpa terpengaruh oleh tekanan sosial; mampu mengontrol perilaku secara mandiri; mengevaluasi diri berdasarkan standar personal. Namun jika yang terjadi sebaliknya, dimana individu memiliki otonomi yang negatif, maka individu cenderung akan terlalu peduli atas harapan dan evaluasi dari orang lain; menjadikan pendapat orang lain sebagai dasar pengambilan keputusan penting; mengikuti tekanan sosial dalam berperilaku dan berpikir. Situasi ini tentu akan membuat komponen sikap dalam aspirasi karir menjadi terganggu, dimana siswa tidak memiliki tujuan yang jelas dalam hidupnya, tidak ada motivasi untuk mencapai tujuan tertentu (Litzky \& Greenhause dalam Smulders, 2009).

\section{Pada komponen Environmental} Mastery pada kesejahteraan psikologis, Ryff (2014) individu ditandai dengan merasa mampu serta memiliki keterampilan untuk mengelola lingkungan; mampu mengontrol kerumitan jadwal kegiatan; memanfaatkan kesempatan yang ada disekitar dengan efektif. Sedangkan sebaliknya jika Environmental Mastery negatif maka individu akan kesulitan untuk mengelola urusan sehari-hari; merasa tidak mampu untuk merubah atau memperbaiki keadaan di sekitar; tidak menyadari adanya kesempatan di sekitar; merasa tidak mampu untuk mengontrol "dunia' di luar dirinya.

$$
\text { Bermasalahnya }
$$

komponen

Environmental Mastery tentu akan menghambat seseorang untuk membuat perubahan, untuk membuat strategi dalam mencapai apa yang ingin dicapai di masa depan. Litzky dan Greenhause (dalam Smulders, 2009) menegaskan bahwa komponen perilaku pada aspirasi karir akan membuat individu membuat rencana aktual dan strategi untuk mencapai tujuan yang diinginkan.

Menurut Danziger dan Eden (2006) menjelaskan bahwa aspirasi karir adalah membina seseorang untuk mewujudkan tujuan karir yang diinginkan. Mereka juga berpendapat bahwa aspirasi karir yang terkait dengan harapan karir seseorang dan persepsi individu adalah gagasan dan penilaian, yang merupakan produk yang terdiri dari proses pengorganisasian mental, pengintegrasian, dan pengakuan terhadap kenyataan yang ada.

Dari penjelasan tersebut dapat dipahami bahwa ketika seseorang memiliki aspirasi karir yang baik, maka individu akan mampu meyakini dirinya, bahwa masa lalu

Citra Abriani Maharani, Program Studi Bimbingan Konseling Fakultas Keguruan dan Ilmu Pendidikan Universitas Lampung. Email: citra.abriani@fkip.unila.ac.id

Yohana Oktariana, Program Studi Bimbingan Konseling Fakultas Keguruan dan Ilmu Pendidikan Universitas Lampung. 


\section{HUBUNGAN KESEJAHTERAAN PSIKOLOGIS DENGAN ASPIRASI KARIR SISWA SMA DI BANDAR LAMPUNG}

merupakan bagian dari proses perubahan mental untuk menjadikan hidup lebih dinamis dan berwarna. Hal ini sejalan dengan pendapat Ryff (2014) pada individu yang memiliki kesejahteraan psikologis pada komponen Purpose in Life positif, akan memiliki tujuan hidup dan perasaan yang terarah; merasa bahwa kehidupan saat ini dan masa lalu memiliki makna; memiliki sebuah keyakinan yang memberikan makna dalam hidup; memiliki sasaran dan tujuan untuk hidup. Begitupun dengan kesejahteraan psikologis komponen Self Acceptance, jika positif maka individu akan memiliki sikap positif terhadap diri; mengakui dan menerima segala kualitas dari aspek diri, baik dan buruknya; merasa positif terhadap kejadian di masa lalu.

Ada beberapa faktor yang mempengaruhi pembentukan dan pengembangan aspirasi karir individu, yang agak berkorelasi dengan kepribadian, minat dan banyak variable psikologis dan sosiologis lainnya. Selain itu faktor-faktor lain yang mempengaruhi aspirasi karir adalah latar belakang ekonomi, hubungan anak dan orangtua, gaya orangtua, kecemasan, jenis kelamin (Huang, 2009).

Huang (2009) juga berpendapat bahwa faktor yang mempengaruhi aspirasi karir siswa di tingkat remaja adalah latar belakang budaya, keluarga, karakteristik pribadi, lingkungan masyarakat dan pengaruh sekolah. Faktor-faktor tersebut juga sesuai dengan teori yang dijelaskan oleh Ryff dan Singer (2008) bahwa ada beberapa faktor yang mempengaruhi kesejahteraan psikologis, yaitu dukungan sosial, status sosial ekonomi, jaringan sosial, religiusitas, dan kepribadian.

\section{SIMPULAN DAN SARAN}

Dari hasil penelitian yang diperoleh, dapat ditarik kesimpulan bahwa terdapat hubungan antara tingkat kesejahteraan psikologis terhadap aspirasi karir siswa SMA di Bandar Lampung, dan dapat diartikan juga bahwa semakin tinggi tingkat kesejahteraan psikologis siswa, semakin tinggi tingkat aspirasi karir siswa.

Hasil penelitian ini memberikan implikasi bahwa siswa diharapkan memiliki kesejahteraan psikologis yang memadai, dan dapat selalu mengaktualisasikan diri secara optimal. Sehingga siswa secara otomatis, akan mengarahkan diri mempersiapkan masa depan, dengan memulai hal-hal yang mendukung tercapainya cita-cita yang diinginkan.

\section{DAFTAR PUSTAKA}

Smulders, A. (2009). Student Career Aspirations: the effect of year of study, gender and personality traits. University of Maastricht.

Akhtar, M. (2009). Applying positive psychology to alcoholmisusing a dolescents.: a pilot intervension. Disertation. United Kingdom: Msc applied positive psychology on University of East London.

Citra Abriani Maharani, Program Studi Bimbingan Konseling Fakultas Keguruan dan Ilmu Pendidikan Universitas Lampung. Email: citra.abriani@fkip.unila.ac.id

Yohana Oktariana, Program Studi Bimbingan Konseling Fakultas Keguruan dan Ilmu Pendidikan Universitas Lampung. 


\section{HUBUNGAN KESEJAHTERAAN PSIKOLOGIS DENGAN ASPIRASI KARIR SISWA SMA DI BANDAR LAMPUNG}

Dorji, J. (2008). Factors Affecting Career Aspirations of Secondary School Leavers in Bhutan (Doctoral dissertation, Mahidol University).

Guerino, P., Harrison, P. M., \& Sabol, W. J. (2011). Prisoners in 2010. Washington, DC: Bureau of Justice Statistics.

Danziger, N., \& Eden, Y. (2006). Student career aspirations and perceptions: The case of Israeli accounting students. Accounting Education: an international journal, 15(2), 113-134.

Gotffredson, L. S. (1981). Circumscription and compromise: A developmental theory of occupational aspirations. Journal of Counseling psychology, 28(6), 545.

Hurlock, E. B. (1980). Psikologi perkembangan. Jakarta: erlangga.

Huang, L. (2009). Gender segregation in student career aspirations in Norwegian secondary schools. In Gender, equality and education from international and comparative perspectives. Emerald Group Publishing Limited.

Nasrudin, M. (2017). Perkembangan Remaja. Journal INSTITUTIONAL REPOSITORY of IAIN Tulungagung (IRIT).

Ryff, C. D., \& Singer, B. H. (2008). Know thyself and become what you are: A eudaimonic approach to psychological well-being. Journal of happiness studies, 9(1), 13-39.

Ryff, C. D. (1989). Happiness is everything, or is it? Explorations on the meaning of psychological well-being. Journal of personality and social psychology, 57(6), 1069.

Ryff, C. D. (2014). Psychological well-being revisited: Advances in the science and practice of eudaimonia. Psychotherapy and psychosomatics, 83(1), 10-28.
Vázquez, C., Hervás, G., Rahona, J. J., \& Gómez, D. (2009). Psychological wellbeing and health. Contributions of positive psychology. Annuary of Clinical and Health Psychology, 5(2009), 15-27.

Citra Abriani Maharani, Program Studi Bimbingan Konseling Fakultas Keguruan dan Ilmu Pendidikan Universitas Lampung. Email: citra.abriani@fkip.unila.ac.id

Yohana Oktariana, Program Studi Bimbingan Konseling Fakultas Keguruan dan Ilmu Pendidikan Universitas Lampung. 